\title{
Design and Demonstration of an Extended Range Hydrogen Fuel Cell Utility Vehicle
}

\author{
C.S. Hearn ${ }^{1}$, M.C. Lewis ${ }^{1}$, R.T. Thompson ${ }^{1}$, D. Chen ${ }^{2}$, J. Hanlin ${ }^{3}$, D. Zuckerman ${ }^{4}$, T. Lindsay ${ }^{4}$
}

1) The University of Texas at Austin - Center for Electromechanics, Austin TX.

2) The University of Texas at Austin - Department for Mechanical Engineering, Austin TX

3) Center for Transportation and the Environment, Atlanta GA

4) Gas Technology Institute, Chicago, IL

hearn@cem.utexas.edu

\begin{abstract}
This paper discusses the design, build, and demonstration of two hybrid electric fuel cell utility vehicles for a program sponsored by DLA (Defense Logistics Agency). The design emphasis for the utility vehicles was range extension over state of the art battery systems using a fuel cell power plant. The design work involved vehicle modeling in PSAT to evaluate different battery technologies and compare the effects of different hydrogen storage technologies on vehicle performance and overall range. The comparative analysis showed that 350 bar compressed hydrogen storage maximized vehicle range and produced a final vehicle design that demonstrated a $300+$ mile range during commissioning trials.
\end{abstract}

\section{INTRODUCTION}

Vehicle propulsion systems based on alternative energy sources have drawn much attention over the past decade. A hybridized vehicle structure has been proposed to take advantage of an alternative energy source to maximize the vehicle range with good overall system performance. The University of Texas at Austin Center for Electromechanics (UT-CEM), in partnership with Gas Technology Institute (GTI) and Center for Transportation and the Environment (CTE), was funded by Defense Logistics Agency (DLA) to design, build, and deliver two extended range hydrogen fuel cell utility vehicles for a yearlong demonstration at the Defense Distribution Depot at Warner Robbins Air Force Base in Georgia (DDWG). The stock vehicle used for the retro-fit was a Columbia ParCar SUV-LN, which is powered by a $48 \mathrm{~V}$ lead-acid battery pack and $14 \mathrm{~kW}$ DC motor as shown in Fig. 1. A primary focus of this program was to assess different hydrogen storage technologies and maximize onboard hydrogen storage to maximize range without sacrificing vehicle performance.

PSAT (Power Train System Analysis Toolkit) was used extensively in the design phase to assess different hydrogen storage technologies, hybrid vehicle configurations, and battery/ultracapacitor options to determine the best design that could extend vehicle range and meet sponsor specifications. PSAT is a forward looking software package developed by Argonne National Laboratories which utilizes Matlab and Simulink. This vehicle modeling program allows the user to evaluate many different design configurations quickly and effectively.

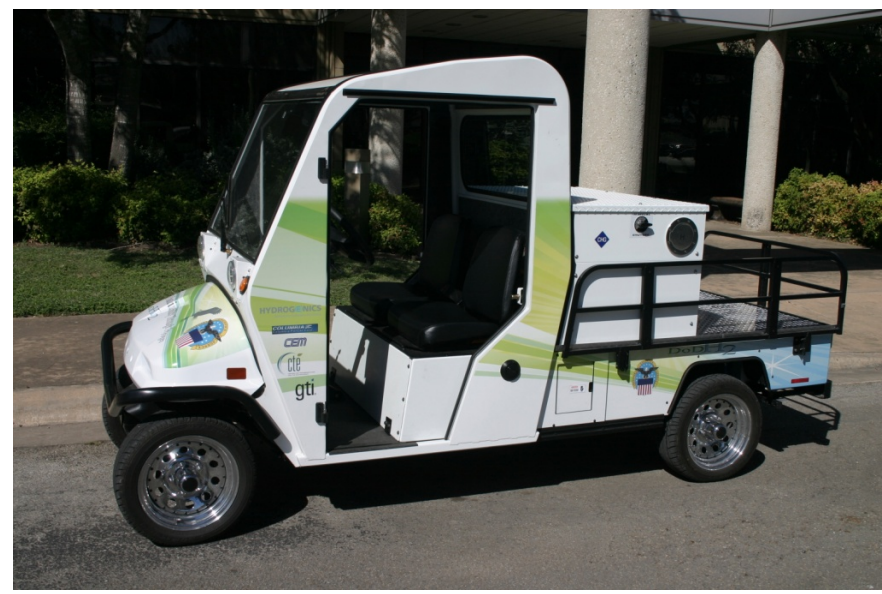

Fig.1. Fuel cell retro-fit of Columbia ParCar SUV-LN with $8.5 \mathrm{~kW}$ fuel cell and $3.7 \mathrm{~kg}$ of onboard hydrogen storage

Similar electric vehicle conversions have been performed in the past. Both Kettering University and Tennessee Tech University have retrofitted GEM cars with PEM fuel cells $[1,2]$. Energy Research Centre of the Netherlands (ECN) upgraded a GEM vehicle with a $5 \mathrm{~kW}$ fuel cell. This vehicle stored $1.3 \mathrm{~kg}$ of compressed hydrogen at 200 bar and had a range of 124 miles [3]. A John Deere Gator was converted by Westinghouse Savannah River Company and utilized metal hydrides to store $2 \mathrm{~kg}$ of hydrogen [4]. This vehicle had a range of 50 miles. UT-CEM reviewed commercially available electric utility vehicles and NEVs (Neighborhood Electric Vehicles) which are powered by $48 \mathrm{~V}$ or $72 \mathrm{~V}$ lead acid battery packs alone and found that the standard vehicle range can vary between 25 to 40 miles $[5,6]$.

This paper reviewed the design procedure for modeling and evaluating different vehicle configurations for maximizing range. The analysis conducted also compared vehicle performance between the current design and a platform with advanced lithium ion batteries. A hydrogen fuel cell with ultracapacitors is introduced to further extend the vehicle range beyond the battery's capability. Various onboard hydrogen storage technologies were evaluated for a fuel cell system. From this analysis, a vehicle platform was chosen for an extended range of 300 miles and validation results are presented. 


\section{DESIGN PROCEDURE AND ANALYSIS}

The primary design requirements for the vehicle were to maximize range while still providing suitable cargo room and mass to meet the sponsor's needs. The base vehicle selected for the retrofit was the SUV-LN produced by Columbia ParCar Corporation. Stock vehicle specifications are shown in Table 1. A $48 \mathrm{~V}, 215 \mathrm{AH}$ lead-acid battery pack powers the vehicle with a manufacturer advertised range of 35 miles.

\section{A. Range extension with advanced battery technology}

A straightforward method to increase range for an all electric utility vehicles is to investigate using higher performance batteries, such as Lithium Ion batteries. Lithium ion batteries offer much higher power and energy storage capability than traditional lead acid batteries, as shown in Table 2

An initial PSAT analysis was performed to evaluate potential improvements from replacing the lead-acid batteries with Altairnano lithium-titanate batteries. The model evaluated vehicle performance over a flat route profile as shown in Fig. 2 with speeds and accelerations comparable to a small electric utility vehicle. To upgrade the vehicle with state of the art batteries, the $48 \mathrm{~V}, 215$ Ah lead acid battery pack is removed and replaced with a $50.6 \mathrm{~V}, 250 \mathrm{Ah}$ lithium titanate battery pack. The lithium titanate batteries decrease the vehicle curb weight by $74 \mathrm{~kg}$, increase the usable stored energy from $5.7 \mathrm{kWh}$ to $10.8 \mathrm{kWh}$, and increase available cargo bed mass from $265 \mathrm{~kg}$ to $339 \mathrm{~kg}$. The PSAT analysis assumed both vehicles are loaded with $408 \mathrm{~kg}$ of additional cargo weight to represent two passengers and additional cargo mass.

Results from the PSAT analysis are listed in Table 3, which shows that the standard stock SUV-LN vehicle, with lead acid batteries has a predicted range of 26 miles over the route. The advanced lithium titanate batteries demonstrate more than double the vehicle range to 61 miles routes. The range extension comes from an increase in onboard energy storage, and an 8 to $10 \%$ decrease in energy usage resulting from decreased vehicle mass and increased battery efficiency.

Table 1. Original specifications for Columbia ParCar SUV-LN electric utility vehicle

\begin{tabular}{|l|l|}
\hline Peak Motor Power & $12.9 \mathrm{~kW}$ peak \\
\hline Continuous Motor Power & $6.5 \mathrm{~kW}$ \\
\hline Gear Ratio & 10.35 \\
\hline Tires & $175 / 50 \mathrm{R} 13$ \\
\hline Battery & Trojan T-145 6V \\
\hline Voltage & $48 \mathrm{~V}$ \\
\hline Capacity & $215 \mathrm{AH}$ \\
\hline Battery Mass & $264 \mathrm{~kg}$ \\
\hline Vehicle Curb Weight & $794 \mathrm{~kg}$ \\
\hline Cargo Capacity & $447 \mathrm{~kg}$ \\
\hline
\end{tabular}

Table 2. Comparison of conventional and advanced battery options

\begin{tabular}{|l|c|c|c|}
\hline & $\begin{array}{l}\text { Trojan } \\
\text { T-145 }\end{array}$ & Saft VL 6A & Altair Nano \\
\hline Battery & $\begin{array}{l}\text { Deep cycle } \\
\text { lead acid }\end{array}$ & $\begin{array}{c}\text { Lithium-Ion } \\
\text { cell }\end{array}$ & $\begin{array}{c}\text { Lithium } \\
\text { Titanate }\end{array}$ \\
\hline $\begin{array}{l}\text { Technology } \\
\text { Description }\end{array}$ & 39 & 64 & 73 \\
\hline $\begin{array}{l}\text { Energy Density } \\
\text { (Wh/kg) }\end{array}$ & 39 & 64 & 72 \\
\hline $\begin{array}{l}\text { Volumetric } \\
\text { Energy (Wh/L) }\end{array}$ & 106 & 136 & 133 \\
\hline $\begin{array}{l}\text { Power Density @ } \\
90 \% \text { Eff. (W/kg) }\end{array}$ & 27 & 360 & 173 \\
\hline $\begin{array}{l}\text { Recharge Times } \\
\text { (hr) }\end{array}$ & 5 to 6 $1 / 5 \mathrm{C}$ & $1 @ 1 \mathrm{C}$ & $6 \mathrm{C}$ \\
\hline Life (cycles) & $500-1000$ & 5000 & 9000 \\
\hline
\end{tabular}

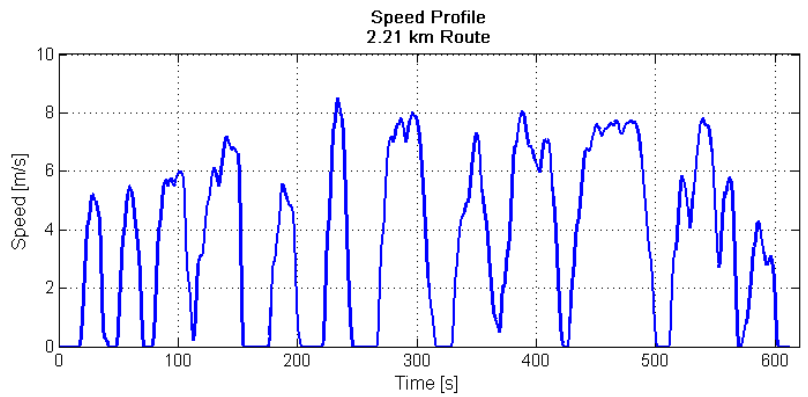

Fig. 2. Route profile used to evaluate vehicle performance

Table 3. PSAT analysis results

\begin{tabular}{|l|c|c|}
\hline & Stock SUV-LN & $\begin{array}{c}\text { SUV-LN with Li-Ion } \\
\text { batteries }\end{array}$ \\
\hline Battery Type & Trojan T-145 6V & $\begin{array}{c}\text { Lithium Titanate } \\
\text { Cells }\end{array}$ \\
\hline Voltage & $48 \mathrm{~V}$ & $51 \mathrm{~V}$ \\
\hline Capacity & $215 \mathrm{AH}$ & $250 \mathrm{AH}$ \\
\hline Battery Mass & $264 \mathrm{~kg}$ & $190 \mathrm{~kg}$ \\
\hline Vehicle Curb Weight & $794 \mathrm{~kg}$ & $720 \mathrm{~kg}$ \\
\hline $\begin{array}{l}\text { Simulated Weight } \\
\text { w/payload }\end{array}$ & $1202 \mathrm{~kg}$ & $1128 \mathrm{~kg}$ \\
\hline Predicted Range & $26 \mathrm{mi}$ & $61 \mathrm{mi}$ \\
\hline Predicted Economy & $193.0 \mathrm{Wh} / \mathrm{mi}$ & $177.2 \mathrm{Wh} / \mathrm{mi}$ \\
\hline
\end{tabular}

\section{B. Range extension with onboard fuel}

To further extend vehicle range, only increasing battery size is not as viable as using onboard fuel due to the increased weight and cost associated with the batteries. Hydrogen gas has a lower heating value of $120 \mathrm{MJ} / \mathrm{kg}$ which far exceeds the energy storage capability of the most advanced batteries, and is an attractive zero emission replacement for an all electric vehicle. Effectively storing hydrogen with the constrained vehicle weight and volume requirements requires attention due to the low density of hydrogen at standard temperature and pressure.

GTI surveyed a wide variety of current and developing hydrogen storage technologies for the extended range utility vehicle. There exist numerous technologies for storing hydrogen which include: compressed gas storage, metal 
hydride storage, pressurized metal hydride, cryogenic liquid hydrogen, and chemical hydride storage, among others. The compressed gas storage is more promising for vehicle applications with respect to volume and weight and has been adapted by the automotive industry. The current fueling infrastructure at the proposed demonstration site, Warner Robbins AFB, is 350 bar compressed hydrogen gas. Focus was placed on storage methods which can utilize the current infrastructure with little to no modifications, namely compressed gas and metal hydride storage. The different hydrogen storage technologies were evaluated in terms of gravimetric capacity ( $\mathrm{kg}$ per $\mathrm{kg}$ of hydrogen stored) and volumetric capacity (grams of hydrogen stored per Liter). The comparison results are summarized in Table 4. Compressed gas storage options included steel and composite tanks between 350 bar and 700 bar. The metal hydride options consisted of conventional metal hydride, which operates at pressures less than $100 \mathrm{psi}$, and pressurized metal hydrides (or hybrid hydrides) which can go up to 2,000 psi to increase storage.

In designing the fuel cell hybrid version, different battery technologies, including lead-acid, $\mathrm{NiMH}$, and Li-Ion, and ultracapacitors were considered to provide transient energy storage and power for the fuel cell. In order to make the final vehicle selection, a decision matrix was used which considered predicted model performance, cost, integration, safety, and availability. From this decision matrix, an $8.5 \mathrm{~kW}$ fuel cell with a $64 \mathrm{~V}, 125 \mathrm{~F}$ ultracapacitor system was chosen due to performance, cost, and availability.

The ParCar SUV-LN has weight and volume constraints that can limit the available amount of total onboard hydrogen.
A parametric study was performed in PSAT to assess the impact of different hydrogen storage technologies to vehicle range and limits on available cargo weight. The ParCar SUV-LN has a gross weight rating of $1240 \mathrm{~kg}$, which is an upper limit for total vehicle weight. By replacing the leadacid batteries with an $8.5 \mathrm{~kW}$ fuel cell, DC-DC converter, and ultracapacitor modules the vehicle curb weight was adjusted from $725 \mathrm{~kg}$ to $659 \mathrm{~kg}$. The difference between the curb weight and gross weight limit is the amount available for 2 passengers (182 kg assumed), hydrogen storage, and end use cargo mass. The PSAT studies assumed a vehicle loading of two passengers.

Table 4. Comparison of proposed hydrogen storage technologies

\begin{tabular}{|c|c|c|c|}
\hline Storage Type & $\begin{array}{c}\text { Gravimetric } \\
\text { Capacity } \\
{[\mathbf{k g} / \text { / } \mathbf{~ H 2}]}\end{array}$ & $\begin{array}{c}\text { Volumetric } \\
\text { Capacity } \\
\text { (Prismatic } \\
\text { Volumes) } \\
\text { [g H2 / L] }\end{array}$ & $\begin{array}{c}\text { Specific Stored } \\
\text { Energy (w/o fuel } \\
\text { cell }) \\
\text { [Wh / kg] }\end{array}$ \\
\hline 400 bar Steel & 136.0 & 12.0 & 245 \\
\hline 350 bar Composite & 23.0 & 12.0 & 1450 \\
\hline 700 bar Composite & 23.4 & 18.1 & 1425 \\
\hline $\begin{array}{c}\text { Conventional Metal } \\
\text { Hydride }\end{array}$ & 116.0 & 18.2 & 287 \\
\hline $\begin{array}{c}\text { Ovonics } \\
\text { Pressurized Metal } \\
\text { Hydride }\end{array}$ & 73.8 & 23.9 & 452 \\
\hline $\begin{array}{c}\text { GTI Metal Hybrid } \\
\text { Hydride }\end{array}$ & 76.7 & 26.5 & 436 \\
\hline
\end{tabular}

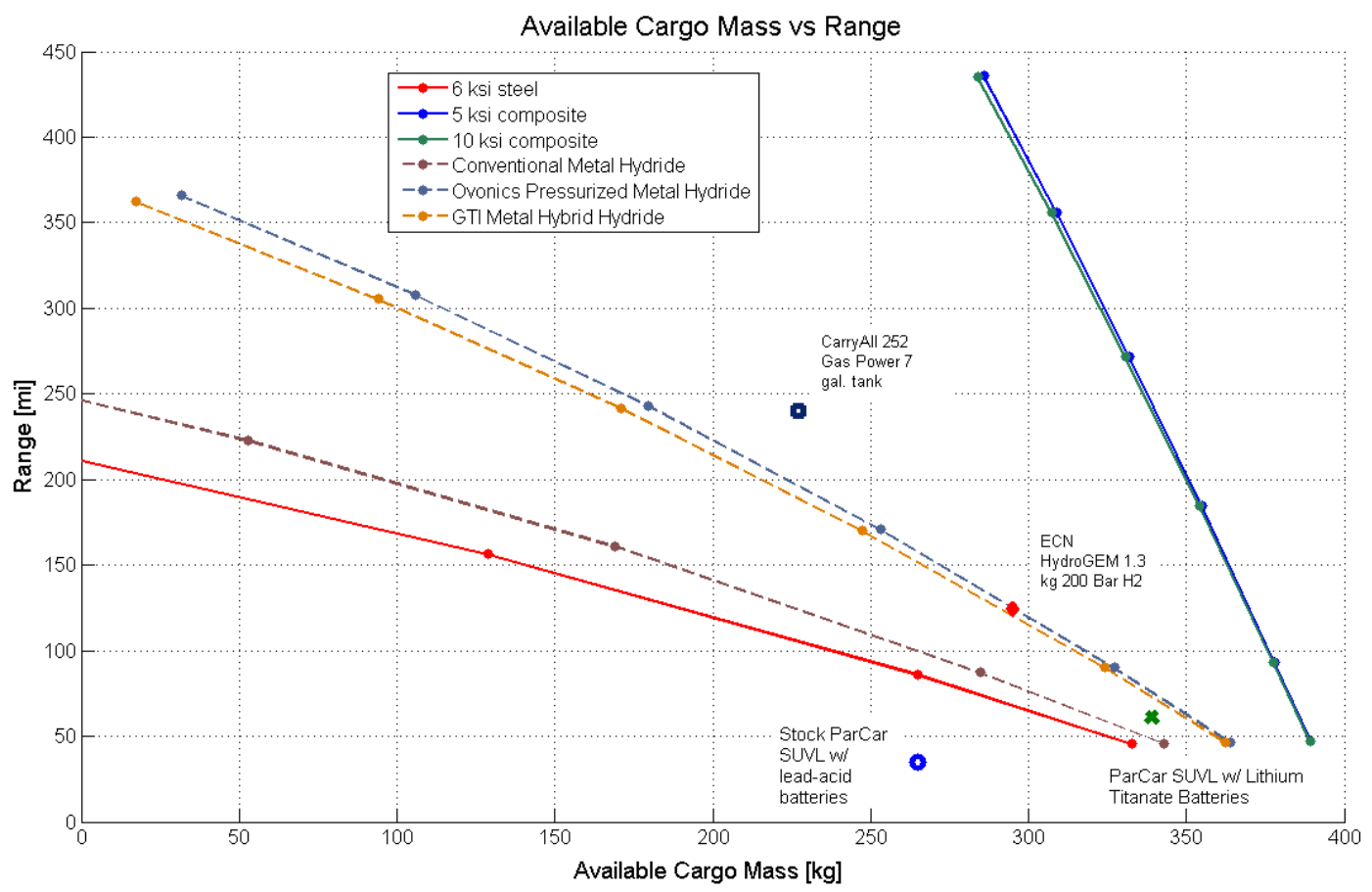

Fig. 3. Comparison study results of hydrogen storage technologies on end vehicle range and remaining cargo capacity 
The results of the parametric study in PSAT are shown in Fig. 3, along with comparisons to the original vehicle plus other vehicles studied, and the variant of the ParCar which used high performance lithium-titanate batteries instead of conventional lead-acid. For each storage technology, as onboard hydrogen storage increases, range increases along with a decrease in available onboard cargo mass. The results show that composite compressed gas outperforms the other hydrogen storage technologies by having the least impact on available cargo mass with increasing range. There is minimal improvement in range and cargo capacity between the 700 bar and 350 bar storage options. The metal hydride options add extra mass to the vehicle, which increases losses, resulting in decreased vehicle range, and reduces available cargo capacity. A drawback to the compressed storage options is the decreased volumetric capacity which is $50-$ $60 \%$ of the metal hydride options.

From the above analysis, the design team chose a vehicle platform, which included an $8.5 \mathrm{~kW}$ fuel cell, ultracapacitors for load leveling, and $3.7 \mathrm{~kg} 350$ bar compressed onboard hydrogen storage. The goal of this design is to give the vehicle a predicted range of 290 to 330 miles depending on cargo weight loading.

\section{Vehicle Retro-Fit and Evaluation}

UT-CEM received two ParCar SUV-LN electric utility vehicles from Columbia ParCar for retro-fitting. The leadacid batteries from the vehicles were removed and replaced with an $8.5 \mathrm{~kW}$ PEM fuel cell from Hydrogenics, an $8 \mathrm{~kW}$ DC-DC boost converter from US-Hybrid, and four $16 \mathrm{~V}$ Maxwell ultracapacitors for dynamic energy storage, as shown in Fig. 4. The DC-DC boost converters raised the output fuel cell voltage from $\sim 30 \mathrm{~V}$ to the operational voltage of $48 \mathrm{~V}$. Since the boost converter can only raise the input voltage, an additional "soft-start" circuit was built in the event of the ultracapacitor voltage falling below $40 \mathrm{~V}$. This "soft-start" circuit consisted of four parallel solid state Synqor buck-boost modules which can fully charge the ultracapacitors from $0 \mathrm{~V}$ to $40 \mathrm{~V}$.

Vehicle supervisory control was performed with a CompactRio, cRio-9025, from National Instruments. The primary function of the supervisory control was to facilitate CAN communication between the fuel cell module and boost converter, operate start-up process controls, handle component faults, and record operational data. The controller also commanded a velocity dependent voltage setpoint to the boost converter to better utilize dynamic energy storage, similar to the system described by Luk and Rosario [7]. The final vehicle specifications are shown in Table 5. The original design analysis suggested the cargo capacity with fuel cell and hydrogen storage would be slightly more than the stock vehicle at $454 \mathrm{~kg}$, but this was reduced to $317 \mathrm{~kg}$ due to potential limits on the rear shocks.

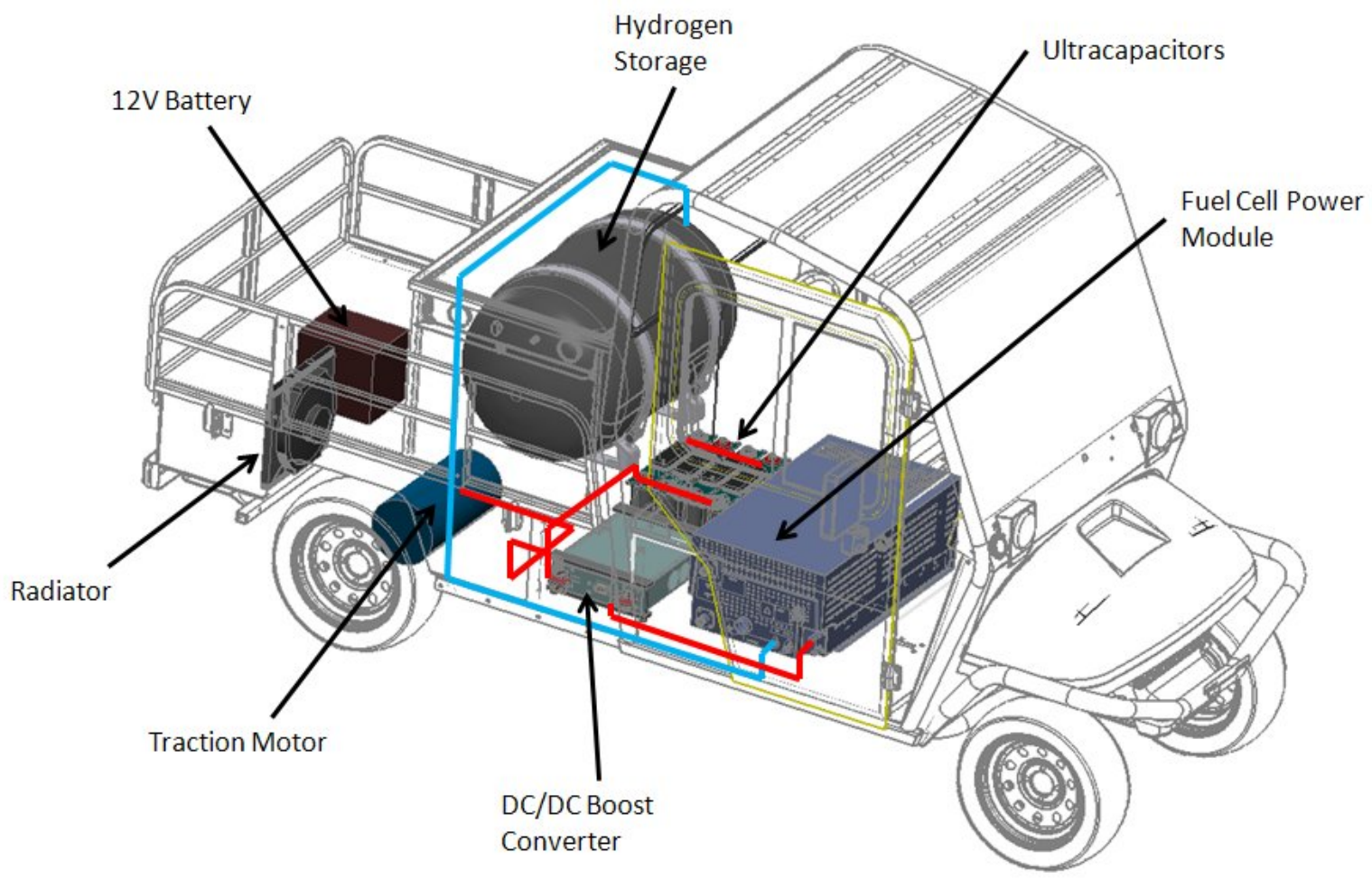

Fig. 4. Layout of integrated components 
Initial demonstrations to verify vehicle range were performed on the Pickle Research Campus (PRC) at The University of Texas at Austin. This campus, where the Center for Electromechanics is located, is relatively flat with speed limits up to $25 \mathrm{mph}$. One vehicle was filled with a full tank of hydrogen weighing $3.7 \mathrm{~kg}$, and driven around the campus until the hydrogen tank pressure reduced to 100 psi. The testing was conducted over a week in different shifts, one of which is shown in Fig. 5. At the end of the testing, the vehicle attained a final range of 309 miles, which agrees with the original PSAT analysis, and demonstrated an average vehicle efficiency of $90 \mathrm{mi} / \mathrm{kg}$ of hydrogen.

Table 5. Retrofitted fuel cell ParCar

\begin{tabular}{|l|l|}
\hline Powertrain & Series Hybrid \\
\hline Prime Mover & $8.5 \mathrm{~kW}$ Fuel Cell \\
\hline Energy Buffer & $64 \mathrm{~V}, 125 \mathrm{~F}$ Ultracapacitor \\
\hline Fuel Storage & $3.7 \mathrm{~kg} 350$ bar compressed H2 \\
\hline Traction Motor & $12.9 \mathrm{~kW}$ \\
\hline Range & $300 \mathrm{mile}$ \\
\hline Cargo Capacity & $317 \mathrm{~kg}$ \\
\hline
\end{tabular}

In November 2010, both vehicles were delivered to Warner Robbins AFB in Georgia for on base use by DDWG personnel. Vehicle usage will be evaluated during a 12 month demonstration period. Currently the vehicles have been showing about 30\% less fuel economy than what was demonstrated at PRC and predicted by the PSAT models. Differences exist with the operation at Warner Robbins AFB. One is that the trip length tends to be less than 2 miles and vehicle use is intermittent, whereas the PSAT analysis and demonstration were assumed continuous driving of the vehicle. Intermittent fuel cell use may prevent the stack from reaching nominal operating temperature and thus reduce efficiency. Further analysis and evaluation may be required to understand this discrepancy.

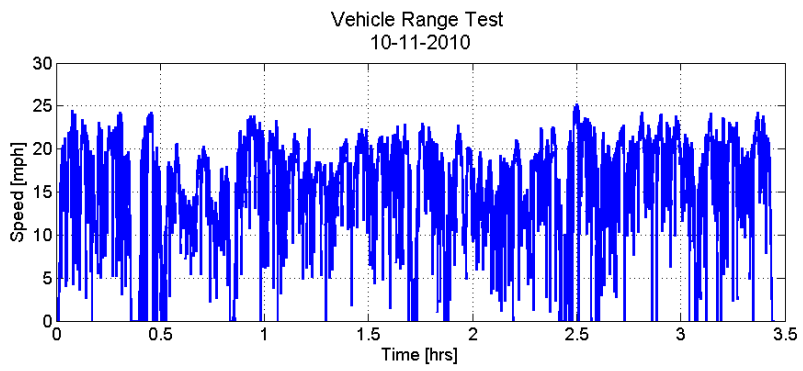

Fig. 5. Sample test data from verification of vehicle range study

\section{CONCLUSION}

This paper presents an overview of the design, analysis, build, and demonstration of two extended range fuel cell utility vehicles. The design showed that composite wrapped pressurized storage is currently the most promising commercially-available hydrogen storage mechanism for this application, which reduces storage mass and extends vehicle range. On road demonstration did verify PSAT analysis for vehicle range under constant driving conditions of over 300 miles. From current usage at Warner Robbins AFB, which involves intermittent use, data shows vehicle range may be reduced by $30 \%$. This discrepancy might be caused by the difference in driving pattern that results in the fuel cell was not operating at its optimal efficiency points.

\section{ACKNOWLEDGEMENTS}

The authors would like to thank the Defense Logistics Agency, Naval Surface Warfare Center - Crane Division, and the Personnel at the Defense Distribution Depot at Warner Robbins Air Force Base in Georgia for the support of this program.

\section{REFERENCES}

1. E.U. Ubong, et al. Ultracapacitor with Ballard Nexa in a GEM Vehicle in a Hybrid Mode. IEEE 0-7803-9 145-4/05, 2005.

2. M.S. Alam and D.W. Gao. Conversion of a Golf Car into a Hybrid Fuel Cell Li-Ion Battery Vehicle and Validation of the Vehicle Model for the 2006 GEM eL Golf Car Using PSAT. IEEE 1-4244-0726-5/06, 2006.

3. ECN. HydroGEM Fuel Cell Vehicle

http://www.ecn.nl/fileadmin/ecn/units/es/pdf/Brochure_HydroGEM.pdf

4. L.K. Heung, T. Motyka, and W.A. Summers. Hydrogen Storage Development for Utility Vehicles. U.S. Department of Energy, Contract No. DE-AC09-96SR18500

5. NEV America. 2002 Columbia ParCar 4-Passenger. US Department of Energy Field Operations Program, 2002.

http://www1.eere.energy.gov/vehiclesandfuels/avta/pdfs/nev/parcar4pa ss.pdf

6. NEV America. 2005 Global Electric Motorcars eL Long Bed Utility. US Department of Energy Field Operations Program, 2004. http://www1.eere.energy.gov/vehiclesandfuels/avta/pdfs/nev/gem2005e longbed.pdf

7. P.C.K. Luk and L.C. Rosario. Power and Energy Management of a Duel Energy Source Electric Vehicle - Policy ImplementationIssues. IEEE 1-4244-0449-5/06, 2006. 